\title{
Models for the study of skin wound healing. The role of Nrf2 and NF-кB
}

\author{
Nikola Ambrozovaa,b, Jitka Ulrichova a,b, Adela Galandakova ${ }^{\mathrm{a}, \mathrm{b}}$
}

\begin{abstract}
Nrf2 and NF-KB transcription factors act in wound healing via their anti-inflammatory and anti-oxidant effects or through the immune response. Studying this process is a matter of some importance given the high cost of wound treatment. A major contribution in this regard is being made by models that enable investigation of the involvement of multiple factors in wound healing and testing new curative substances. This literature review was carried out via searches in the PubMed and Web of Science databases up to 2016. It covers skin wound healing, available models for its study (part I), the role of Nrf2 and NF-KB, substances that influence them and whether they can be used as markers (part II). Was found that in vitro assays are used for their availability but a holistic view must be established in vivo. In silico approaches are facilitating assessment of a vast amount of research data. Nfr2 and NF-KB play a crucial and reciprocal role in wound healing. Nrf2 controls repair-associated inflammation and protects against excessive accumulation of $\mathrm{ROS}$ while Nf-KB activates the innate immune reaction, proliferation and migration of cells, modulates expression of matrix metalloproteinases, secretion and stability of cytokines and growth factors for wound healing.
\end{abstract}

Key words: skin wound healing, in vitro and in vivo models, Nrf2, NF-KB

Received: September 13, 2016; Accepted with revision: December 13, 2016; Available online: January 6, 2017

https://doi.org/10.5507/bp.2016.063

${ }^{a}$ Department of Medical Chemistry and Biochemistry, Faculty of Medicine and Dentistry, Palacky University Olomouc, Czech Republic bInstitute of Molecular and Translational Medicine, Faculty of Medicine and Dentistry, Palacky University Olomouc, Czech Republic Corresponding author: Adela Galandakova, e-mail: galandakova.a@seznam.cz

\section{INTRODUCTION}

According to the data, between 1 and $2 \%$ of people experience a chronic wound during their lifetime ${ }^{1}$ and this number will grow due to the rapid rise in the elderly population ${ }^{2}$ because the prevalence of non-healing wounds is highly correlated with age ${ }^{3}$.

The most serious work now is the testing of new drugs and substances that can improve wound healing ${ }^{4}$ based on knowledge of the general kinetics of normal healing as well as under various pathological conditions (e.g. diabetes mellitus ${ }^{5}$, immunosuppressed hosts ${ }^{6}$ etc.). These facts are also used in forensic medicine for determining the age of lesions ${ }^{7}$. Wound healing components are tested as solutions, gels and ointments or in more complex wound care structures (e.g. hydrogel systems ${ }^{8,9}$ ).

\section{WOUND HEALING AND ITS STUDY}

Wound healing is a process which ensures the restoration of skin integrity. Intact skin is necessary for almost all of its functions; especially its primary function as a protective barrier against the environment ${ }^{10}$, which prevents the entry of microorganisms that can cause nonhealing wounds. There are three phases of wound healing: inflammation, proliferation and remodelling (see Fig. 1), although sometimes four are mentioned when coagulation to stop bleeding after injury is considered a separate phase.

The first phase, which starts after injury, is inflammatory. It is characterised by reactions mediated by cyto- kines, chemokines and growth factors. These substances are produced by cells that migrate to the wound area ${ }^{11}$ and afterwards cell proliferation, migration and differentiation are activated ${ }^{12}$. It can be divided into the early (1-2 days after injury) and the later (days 2-3) inflammatory phase. While in the early phase, the complement is activated and leads to the infiltration of granulocyte neutrophils, blood monocytes changing into tissue macrophages is typical of the later phase ${ }^{13}$. The task of this phase is initiating wound repair.

During the second - the proliferation phase - fibroblasts migrate inward from the edges of the wound and produce proteoglycans, glycosaminoglycans and collagens which create granulation tissue. The migration is activated by basic fibroblast growth factor (bFGF) and transforming growth factor (TGF) produced by macrophages and platelet-derived growth factor (PDGF) from platelets. It is also chemotactic ${ }^{14}$. In this phase keratinocytes and endothelial cells also proliferate ${ }^{15}$.

The final phase is remodelation and contraction of the wound, which starts after the formation of the granulation tissue. Conversion of the granulation tissue to scar tissue is accomplished by remodelation of the extracellular matrix ${ }^{16}$. Wounds never reach the same level of tissue strength ${ }^{17}$.

\section{WOUND HEALING MODELS FOR THE SKIN}

Wounds can be divided according to their healing time into acute and chronic ${ }^{18}$, where the healing process lasts longer than 12 weeks after the initial insult ${ }^{17}$. Another classification can be according to the mechanism of origin 


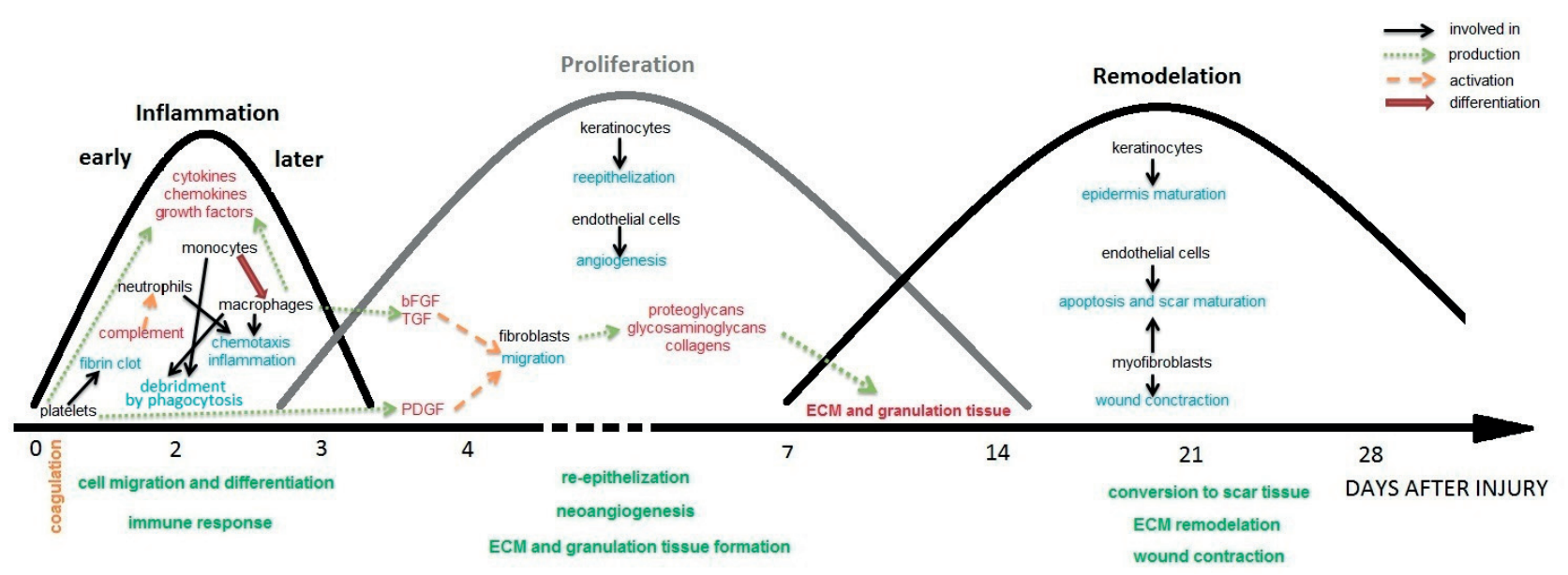

Fig. 1. Phases of wound healing: processes, cells and factors involved.

FGF - basic fibroblast growth factor; ECM - extracellular matrix; PDGF - plateled-derived growth factor; TGF - transforming growth factor.

(mechanical - e.g. laceration, puncture, bruise; chemical - acids and alkalis; thermal - burns, scalds, frostbites; actinic - radiation) or the depth of the wound (superficial and deep) (ref. ${ }^{19}$ ). Special models exist for all these types of wounds and for healing under many unusual conditions, e.g. diabetes mellitus ${ }^{20,21}$, transplantations ${ }^{22}$, skin grafts, cutaneous ischemia and reperfusion injury, ulcers, decubitus $^{23}$, foreign bodies ${ }^{24}$, and stress situations ${ }^{25}$.

In this review, wound healing models for the skin are divided according to the design of the experiment into: in vitro, in vivo, ex vivo and in silico.

\section{In vitro assays}

In vitro models are created from various types of the primary cell cultures or cell lines, of animal or human origin. The most often used are skin keratinocytes and fibroblasts. For more complex models, endothelial cells, macrophages ${ }^{24}$, melanocytes and Langerhans cells ${ }^{26,27}$ are also utilized. Primary human dermal cells are cultivated from the skin of healthy donors who undergo surgical intervention (plastic surgery, circumcision) or directly donate a skin specimen ${ }^{28}$. From specific layers of skin tissue explants skin keratinocytes (epidermis and stratum corneum), fibroblasts (dermis) and melanocytes (splitthickness skin) (ref. ${ }^{27}$ ) can be isolated using distinctive protocols. Primary endothelial cells are isolated from the umbilicus (human umbilical vein endothelial cells HUVEC) or the foreskin (human dermal microvascular endothelial cells) (ref. ${ }^{29}$ ). Macrophages can be obtained from blood monocytes or rarely from bone marrow ${ }^{30}$ and Langerhans cells are derived as a subpopulation of dendritic cells from CD34+ haematopoietic progenitors due to granulocyte macrophage-colony stimulating factor and tumour necrosis factor- $\alpha$ (ref. $\left.{ }^{27}\right)$. Among the human cell lines used in these models are e.g. immortalized human skin keratinocytes (HaCaT) (ref. ${ }^{31,32}$ ) and endothelial cells (e.g. EA.hy926) (ref. $\left.{ }^{4}\right)$. The animal cell lines include mouse fibroblasts L929 (ref. ${ }^{32}$ ) or Balb/3T3 (ref. ${ }^{33}$ ), keratinocytes (XB-2) as well as their progenitors (MPEK-BL6) (ref. ${ }^{33}$ ) or the murine macrophage RAW264.7 (ref. ${ }^{33,34}$ ). The main advantages of the cell lines are that all cells have the same features and can be cultivated for a long time. On the other hand, immortalized cells are transformed and there are deviations from the normal cells ${ }^{35}$, whereas the primary cells have various parameters that depend on the donor (e.g. age, gender and ethnicity) and enable a lower number of passages.

In vitro models could also be created from several kinds of cells (co-cultures). The simplest co-cultures are constructed from primary dermal fibroblasts and primary epidermal keratinocytes ${ }^{36}$ or HaCaT (ref. ${ }^{37}$ ). The keratinocytes have to be seeded on a collagen-coated surface or on a cell monolayer e.g. fibroblasts ${ }^{38}$, HUVEC or both ${ }^{39}$. These elementary co-cultures are one of the ways to prepare a model that is closer to actual skin. Approaches using stem cells for wound healing improvement seem to also be very promising, because these cells excrete many healing mediators into the culture medium such as TGF- 31 , PDGF, bFGF, keratinocyte growth factor (KGF), vascular endothelial growth factor (VEGF), interleukin (IL-) 6 and IL-8 (ref. ${ }^{32,40}$ ). Stem cells can be used indirectly through conditioned medium ${ }^{32,40,41}$ or directly co-cultured with e.g. dermal fibroblasts ${ }^{40}$ up to more complex structures such as the dermis ${ }^{42}$. In both cases positive effects on wound healing were observed ${ }^{32,40,41}$.

Another possibility is directly preparing a three-dimensional (3D) skin model. This model can be created from one type of cell or from co-cultures ${ }^{37,43}$. The 3D structure is achieved with special scaffolds (hydroge ${ }^{44}$, collagen matrices and lyophilized membranes, inert filters or de-epidermized dermis ${ }^{42}$ ). Commercially available kits can be used to prepare the 3D structure that include a special surface for seeding the cells $\left(\right.$ EpiDerm ${ }^{\mathrm{TM}}$ or EpiSkin $^{\mathrm{TM}}$ for keratinocytes that represent the epidermis or EpiDermFT ${ }^{\mathrm{TM}}$ that includes fibroblasts as the der$\mathrm{mis}^{28}$ ). Some models of reconstructed human skin can also be populated with Langerhans cells and/or melanocytes. These more complex models are used for studying cell - cell or cell - matrix as well as dermal - epidermal interactions $\mathrm{s}^{42}$ and observing cell migration in structures similar to the extracellular matrix ${ }^{45}$. Other fields of study are the response of cells to pharmacological agents, their 
growth and other biological factors and their effect on wound healing ${ }^{42}$. A great benefit of the artificial skin constructs is the possibility of testing ultraviolet (UV) radiation $^{46}$ or irritating noxae and obtain initial data without using an animal ${ }^{47}$.

The advantages of in vitro models are price (they are relatively cheap), simplicity and the ethical considerations that are not as complex as with in vivo models. Inherent heterogeneity can be excluded when the same cells are used, as can changes in the environment ${ }^{24}$ and the influence of the entire organism ${ }^{26}$. Their disadvantage is the problem of extrapolating results to the whole organism ${ }^{24}$.

\section{In vivo assays}

In vivo models are more expensive, demanding and involve many ethical considerations compared to in vitro ones, but the results with a holistic approach are often irreplaceable ${ }^{24}$. It makes it possible to evaluate the interplay of the host immune response with external intervention that is crucial in contaminated wounds ${ }^{48}$. Sometimes the factors have different effects in vivo and in vitro - e.g. TGF- $\beta$ promotes angiogenesis in vivo while in vitro it inhibits proliferation and the growth of endothelial cell monolayers. There are more explanations, but one of them suggests a connection to macrophages that produce other angiogenesis-stimulating factors ${ }^{49}$.

In vivo assays can be divided into animals and humans. Animals are used more often because only small and clean wounds ${ }^{24}$ can be created in humans, usually using the sun-protected area of the forearm on a non-dominant $\operatorname{limb}^{50}$. With this arrangement, two wounds can be made, in an ideal case one for each arm, and one of them can serve as a control ${ }^{24}$. If we ignore the fact, that there are differences between human and animal skin, testing on people has another invaluable benefit: the tested person can evaluate pain during the wound process. Depressive symptoms are too difficult to measure in animals ${ }^{50}$ and humans are also better for assessment of psychological stress, although it is possible test stress in e.g. mice ${ }^{25}$.

Because most experiments aim to extrapolate to humans, mammals are usually used, although e.g. chicken chorioallantoic membrane can be used for angiogenesis assays $^{51}$ and the effect of stress on wound healing has been investigated in lizards ${ }^{52}$. Rats, mice, pigs and rabbits are the most frequently used animals. Hamsters ${ }^{24}$, dogs, cats, sheep, horses and ponies ${ }^{53}$ are also utilized. Porcine skin is the closest to human, due to its composition ${ }^{24}$ as well as its tight skin type and mechanism of wound closure (only re-epithelization) (ref. ${ }^{53}$ ). For example, rodents have a special muscle panniculus carnosus that facilitates healing due to wound closure contraction, and that is why mice, rats, hamsters and rabbits heal more rapidly than humans ${ }^{24,53}$. To avoid this phenomenon, scientists make a wound e.g. on rabbit ears where the contraction does not occur $^{24}$. There are many differences between the thickness of particular layers of human and animal skin and there is also a large variability in the number of hairs per $\mathrm{cm}^{2}$ (ref. ${ }^{54,55}$ ) (see Table 1). When selecting between mouse and rat, rat skin strata and whole skin thickness are closer to human than those of mice ${ }^{56}$. Knowledge of interspecies and intraspecies differences helps with the interpretation and extrapolation of results between species ${ }^{53}$.

Animal species as well as individuals within a species differ in size, and that is why animals are characterized by weight. The number and the area of wounds that can be made depend on the animal's size and the part of the body. The smallest wounds, on the order of several-mm punches, can be made in mouse embryos ${ }^{57}$, round wounds up to $2 \mathrm{~cm}$ in diameter are possible in rats ${ }^{58}$, and in pigs wounds with areas of tens of square centimetres can be studied $^{59}$. The biggest free surface is the dorsum, which is also difficult for an animal to reach, and that is why

Table 1. Comparison of skin composition between human, domestic pig, hairy mouse, hairy rat and rabbit ${ }^{24,53-56,141-154}$.

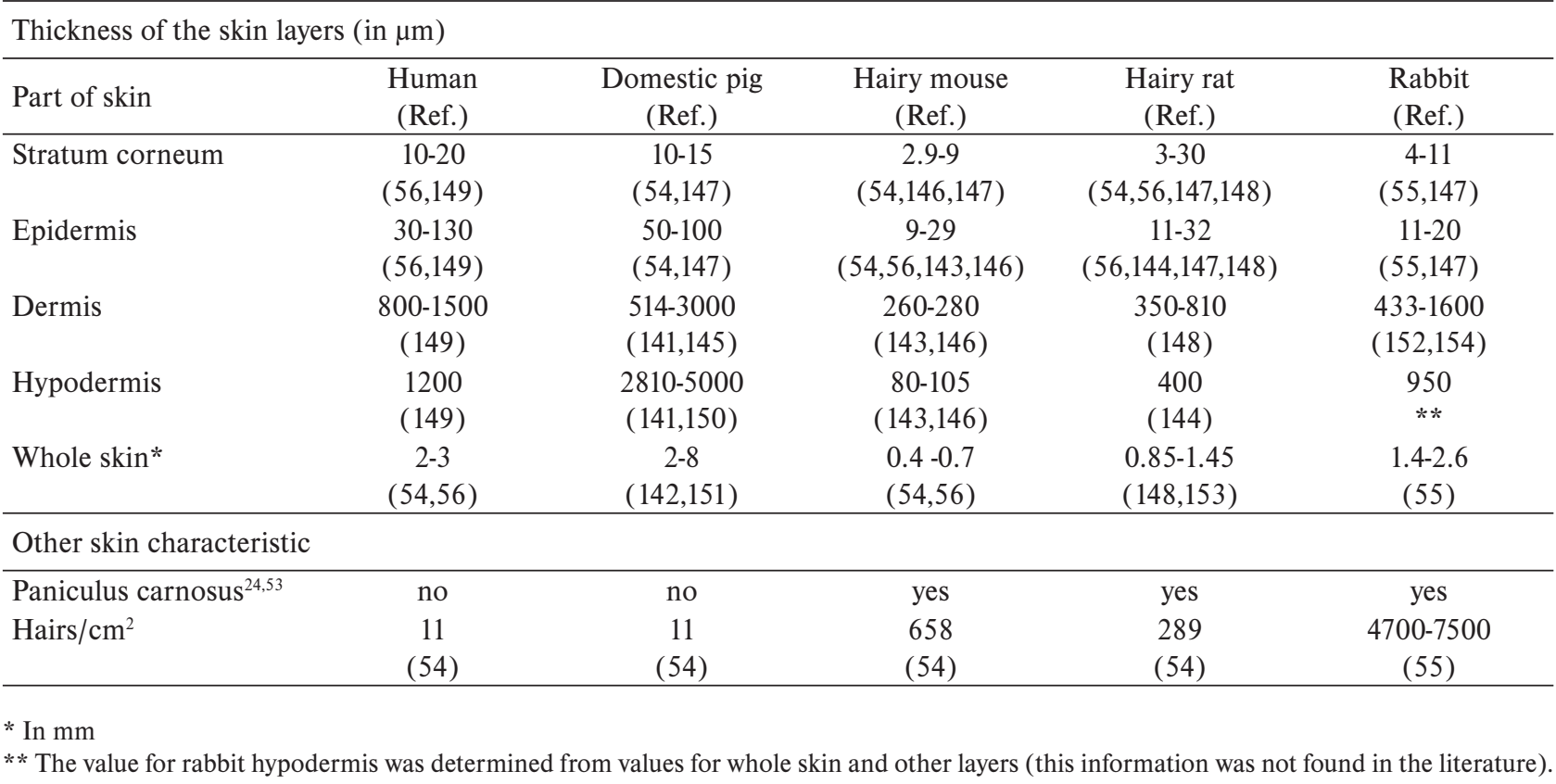


this area is often used ${ }^{24}$. Pigs are also very useful because their size enables multiple wounds to be studied together on the same animal (control and tested influence or dose and time-dependent experiments) (ref. $\left.{ }^{60}\right)$.

Special models exist for each part of the healing process as well as for various conditions ${ }^{24}$ such as impaired wound healing on diabetic and fat animals ${ }^{21,61}$. In particular mice are highly relevant for skin biology studies because many human disease models, knockout strains and transgenic tools can be used with them ${ }^{23}$. Hairless or nude animals provide a significant advantage for some research in that it is easier to make and observe a wound, while a hairy animal has to be shaved first. However, the architecture of hairless mouse skin is quite different from humans ${ }^{24}$. Besides the selection of the correct animal model, good laboratory practice must not be overlooked animals have to be acclimatized after their acquisition for a few days before the experiment starts, the wound must be inflicted under general anaesthesia ${ }^{60}$ and the animal must be kept clean and watched carefully. Finally, it must be noted that current legislation in the European Union, Israel, India and the State of São Paulo in Brazil only allows drugs for wound healing to be tested on animals, and there is an ongoing search for new approaches that do not have to rely on animal studies ${ }^{62}$.

However it is not only research projects that can provide new information about wound healing issues. Clinical vet practice may also have a significant contribution to make in this field. Especially with dogs and cats, vets treat many kinds of wounds and injuries that are also problems for humans, such as thermal injuries, surgical site infections, pressure ulcers and ischemic wounds but also ballistic and degloving injuries, endocrinopathies and immunosuppression, impaired healing and oncological treatment. And of course animals are great examples for studying bite wounds ${ }^{53}$.

\section{Ex vivo assays}

At the interface between in vitro and in vivo models are ex vivo approaches. Full thickness skin explants (biopsies and then skin tissue culture) can be obtained from animals and humans, both living and dead. Even if we can take larger sections of skin from dead organisms, harvesting from a living body enables the samples taken to be immediately processed and so avoid post mortem changes. The use of laboratory animals is a great advantage, since they can be sacrificed when the researcher needs to start an ex vivo experiment with skin. From living humans either small pieces can be obtained thanks to volunteer donors ${ }^{63}$ or larger sections of skin when a person undergoes plastic reduction surgery (mammo- or abdominoplasty). These ex vivo models offer a simple and cost-effective viable design for studying wound healing while preserving epitopes for translation ${ }^{64}$.

The collected skin is usually disinfected with ethanol, freed from subcutaneous fat, rinsed with physiological solution and place on a suitable surface ${ }^{64,65}$ such as dishes coated with collagen I (ref. ${ }^{64}$ ) or onto inserts ${ }^{66}$. The wounds are then created and exposed to the tested agents (cytokines, matrix metalloproteinase inhibitors, silver, natural compounds etc.) (ref. $\left.{ }^{64,66}\right)$. The viability of cultured explants can be evaluated e.g. by their lactate dehydrogenase activity ${ }^{64}$. When the explants are obtained from volunteer donors preventive effects on wound healing can also be examined - a substance is topically applied to the skin before harvesting ${ }^{63}$. There are many specialised methods that evaluate the influence of stretching on healing ${ }^{67}$, or angiogenesis and blood vessel permeability during the restorative process (ex vivo perfusion) (ref. ${ }^{68}$ ). Ex vivo models can also be very useful for studying the changes in a transdermal delivery system after an injury or for forensic practice, where it is essential to determine the age of a wound and distinguish between a wound created ante- or post-mortem ${ }^{10}$.

\section{In silico assays}

As the amount of knowledge about wound healing increased, theoretical models were developed ${ }^{69,70}$. These are primarily used in the research field. It has been found that all chronic wounds have notably comparable healing paths and also similar inflammatory profiles. In the pharmaceutical industry, these findings may result in the determination of new targets for curative drugs. For clinical practice, in silico approaches will perhaps provide options for personalized treatment if the model is improved with individual genetic data ${ }^{71}$.

\section{THE POSSIBILITIES OF WOUND FORMATION AND EVALUATION METHODS}

One of the most important things to ensure is that all tested wounds should be uniform in location, diameter and depth, and also the conditions during wound creation should always be the same. It is easier to create an acute wound than a chronic one. The defect is usually made mechanically (cut, scratch) and/or thermally (heat or cold, radiation). Also chemicals such as acids (sulphuric, triacetic...), alkalis (sodium hydroxide) and nitrogen mustard could be used ${ }^{72}$. While mechanical damage enables observation of re-epithelialization, chemical wounds can be used to study stromal activation ${ }^{73}$. Sometimes it is useful to cover lesions to prevent them from drying out ${ }^{41}$.

Chronic wounds models usually combine acute wound creation and then the injury is exposed to some sort of long-term effect. For in vitro applications, a collagen gel matrix with serum protein which mimics the wound bed of a chronic lesion can be used and e.g. bacterial infection studied $^{74}$. In vivo true chronic wound models in animals are very difficult to establish because chronic defects do not occur in them and the majority of in vivo information about non-healing wounds are obtained from clinical practice with humans ${ }^{75}$. The use of these models lies in bacteriology testing when the particular bacterial strains or their lipopolysaccharides are applied to rodent skin for several weeks and scientists observed the immune system response $\mathrm{e}^{76}$ or bacterial film formation on a chronic thermal injury ${ }^{77}$. Other research is engaged in ischemic 
Table 2. Markers for particular phases and processes in wound healing ${ }^{12-14,17,155}$.

\begin{tabular}{|c|c|c|}
\hline Phase & Process & Involved molecules that can be used as markers \\
\hline \multirow[t]{4}{*}{ Inflammatory } & Inflammation & IL-1, IL-6, IL-8, IL-10, NF-кB, Nrf2, MMP-2, HGF, PDGF, TGF- $\beta$, TNF- $\alpha$ \\
\hline & Cell migration & EGF, HGF, KGFs, NF-kB, NGF \\
\hline & Cell differentiation & IL-10, EGF, FGFs, TGF- $\beta$ \\
\hline & Immune response & IL-10, IL-10, IL-27, PDGF, TGF- $\beta$, G-CSF, TNF- $\alpha$ \\
\hline \multirow[t]{5}{*}{ Proliferative } & Proliferation & $\begin{array}{l}\text { IL-1, IL-10, EGF, FGFs, IGF-1, KGFs, NF- } \kappa B \text {, NGF, PDGF, TGF- } \alpha \text {, TGF- } \beta \text {, } \\
\text { G-CSF, GM-CSF, TNF- } \alpha\end{array}$ \\
\hline & Reepithelization & IL-1, IL-6, EGF, FGFs, HGF, NF-кB, PDGF, TGF- $\alpha$,TGF- $\beta 1$ \\
\hline & Angiogenesis & IL-1, IL-6, MMP-2, FGFs, HGF, TGF- $\beta$, VEGF \\
\hline & ECM tissue formation & IL-4, IL-27, IGF-1, PDGF, TGF- $\beta$ \\
\hline & Granulation tissue formation & EGF, FGFs, HGF, TGF- $\alpha$, TGF- $\beta$ \\
\hline \multirow[t]{3}{*}{ Remodeling } & ECM remodelation & IL-1, IL-6, MMPs, TIMPs, PDGF, TGF- $\beta$ \\
\hline & Wound contraction & IL-8, IL-10, FGFs, NGF, TGF- $\beta$ \\
\hline & Scaring (fibrosis) & MMP-2, MMP-9, TIMP-1 \\
\hline
\end{tabular}

ECM - extracellular matrix; EGF - epidermal growth factor; FGFs - fibroblast growth factors; G-CSF - granulocyte-colony stimulating factor; GM-CSF - granulocyte macrophage-colony stimulating factor; HGF - hepatocyte growth factor; IGF-1 - insulin-like growth factor; IL - interleukin; KGFs - keratinocyte growth factors; MMP - matrix metalloproteinase; NF- $\mathrm{B}$ - nuclear factor- $\mathrm{kB}$; NGF - nerve growth factor; Nrf2 - nuclear factor-erythroid 2 (NF-E2)-related factor 2; PDGF - platelet-derived growth factor; TGF - transforming growth factor; TIMP - tissue inhibitor of metalloproteinases; TNF- $\alpha$ - tumour necrosis factor- $\alpha$; VEGF - vascular endothelial growth factor.

wounds e.g. on rabbit ears (the nutrient arteries are divided and an incision wound is created) (ref. ${ }^{78}$ ). These models can also help with testing therapeutic strategies ${ }^{74}$.

The wound and study of the healing process can be observed morphologically. The area, depth and scar formation of the wound are monitored by cell migration, neovascularization and possible deposition of the tested substance (e.g. silver) (ref. ${ }^{63,64,66}$ ). The re-epithelization and scar formation are measured by the incorporation of 5-bromo-2-deoxyuridine ${ }^{65}$. During inflammation, blood vessel permeability increases, so it is also useful to observe this in vivo (in mice by intravenous injection with fluorescein isothiocyanate dextran $\left.{ }^{68}\right)$. When a new compound is tested for sanative effects, we must not neglect viability tests such as 3-(4,5-dimethylthiazol-2-yl)-2,5-diphenyltetrazolium bromide or neutral red assay or the determination of ROS generation as an oxidative stress marker.

However, today it is almost inevitable that each process is studied at the level of mRNA as well as protein expression. Typical markers are known for the inflammation, proliferation and remodeling phases in general or for more concrete processes (coagulation, immune response and cell activation and differentiation, proliferation, re-epithelization, angiogenesis, extracellular matrix remodelation, epidermal-mesenchymal interaction ${ }^{65}$ etc.). Table 2 provides a brief overview of the habitually studied molecules regulating various wound healing processes and which can be used as markers for the skin restoration process.

There are many ways in which wound healing can be evaluated and thus determine the effect of the compound/ treatment method or its influence in general. Briefly, molecular methods and the determination of markers are necessary when a new compound is being studied, while in experiments closer to clinical practice (e.g. the testing of healing systems such as hydrogels, biodegradable materials, scaffolds) the histology becomes more important (a lesion's area or thickness and the overall morphology of healing).

\section{THE ROLE OF NRF2 AND NF-KB, AND INTERCONNECTIONS BETWEEN THEM DURING WOUND HEALING}

Scientists are currently searching for interconnections between various processes to obtain a deeper understanding of skin restoration. Transcription factors Nrf2 and $\mathrm{NF}-\kappa \mathrm{B}$ are now frequently studied for their key role in oxidative stress and inflammatory reaction. The complicated network of their regulatory effects is also involved in wound healing. A summary of their impact on this field and evaluation of their use as markers is given below.

\section{Nrf2 in the wound healing}

Nuclear factor-erythroid 2 (NF-E2)-related factor 2 (Nrf2) is a cytosolic transcription factor. Under non-stressful conditions, it is sequestered by Kelch-like ECH-associated protein (Keap1) which marks Nrf2 for proteasomal degradation ${ }^{79,80}$. In cells under harmful stress, Nrf2 is separated from its inhibitor protein and translocates into the nucleus ${ }^{79,81-83}$. In the nucleus Nrf2 binds to the antioxidant response elements (ARE), which requires heterodimerization with the small Maf proteins ${ }^{80}$. ARE are located in the promoter region of genes that code many antioxidant and phase II detoxifying enzymes. These enzymes are important in cellular defence by enhancing the removal of cytotoxic electrophiles and ROS (ref. ${ }^{84}$ ).

The up-regulated expression of $\mathrm{Nrf} 2$ (see Fig. 2) was observed $^{85}$ upon skin injury. The main function of Nrf2 during wound healing is protection against the excessive accumulation of endogenous ROS, which are produced 


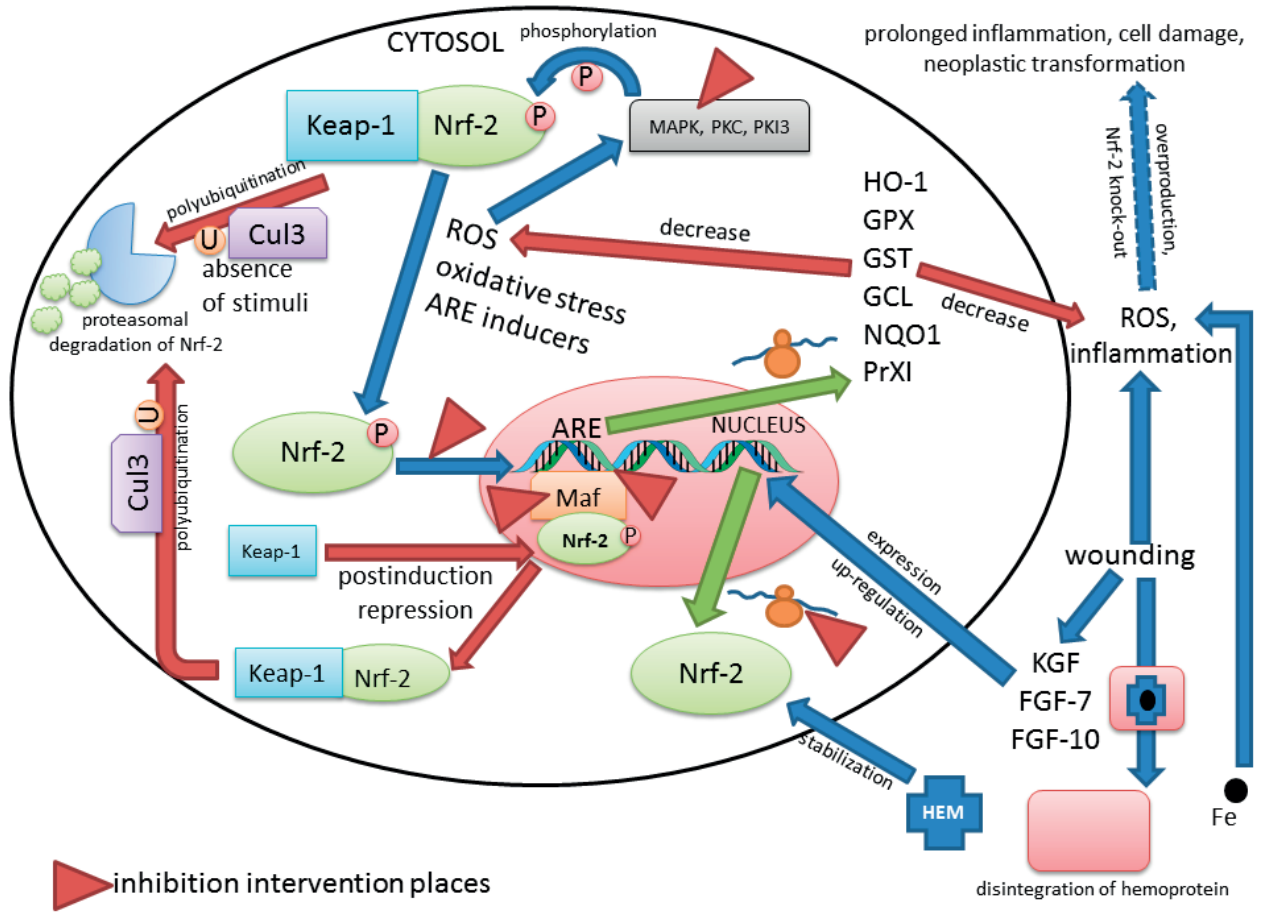

Fig. 2. Nrf2 pathway in wound healing.

ARE - antioxidant response elements; FGF - fibroblast growth factor; GCL - glutamate cysteine ligase; GPX - glutathione peroxidase; GST - glutathione S-transferase; HO-1 - heme oxgenase-1; Keap1 - Kelch-like ECH-associated protein; KGF - keratinocyte growth factor; MAPK - mitogen-activated protein kinases; Nrf2 - nuclear factor-erythroid 2 (NF-E2)-related factor 2; NQO1 - NAD(P)H quinone oxidoreductase; P - phosphorylation; PKC - protein kinase C; PI3K - phosphatidylinositol 3-kinase; PrXI - peroxiredoxin I; ROS - reactive oxygen species; TGF - transforming growth factor; $\mathrm{U}-$ ubiquitination.

in large amounts in wounded and inflamed tissues. It was found that there is a pronounced expression of $\mathrm{Nrf} 2$ in macrophages and keratinocytes localized in hyperproliferative wound epithelium. Prolonged inflammation was found in knockout animals ${ }^{82}$, although it was not observed to affect skin morphogenesis. This means that Nrf2 plays an important role during the resolution stage of inflammation $^{86}$, but not in the re-epithelization of skin wounds ${ }^{81}$ ${ }^{87}$. Thus Nrf2 has been identified as controlling repairassociated inflammation under physiological conditions. This factor is also irreplaceable in diabetic wound healing because the tissues of a patient with diabetes mellitus already exhibit higher oxidative stress. This stress further increases after injury, and it has been established that pharmacologically elevated levels of Nrf2 are beneficial for impaired wound healing in diabetes mellitus ${ }^{88}$.

\section{Nrf2 inductors}

The Nrf2 pathway is activated under stress conditions, especially by ROS (ref. ${ }^{89}$ ) and ARE inducers. These inducers can be endogenous $\left(\mathrm{NO}, \mathrm{H}_{2} \mathrm{O}_{2}\right.$, 4-maleylacetoacetate, 4-hydroxynonenal, nitro-oleic acid, 15-deoxy-delta-12,14-prostaglandin J2) or exogenous, including phytochemicals (quercetin, oleanolic acid, genistein ${ }^{90}$, resveratrol, sulphoraphan ${ }^{89}$, curcumin $^{91}$, zerumbone ${ }^{92}$, 4-ketopinoresinol ${ }^{93}$ ), therapeutics (e.g. nimesulide, acetaminophen) and environmental agents (paraquat, metals
- $\mathrm{Cd}^{2+}, \mathrm{Hg}^{2+}, \mathrm{Au}(\mathrm{I})$, silica, nanotubes) $\left(\right.$ ref. $\left.{ }^{90}\right)$. The gene encoding Nrf2 is regulated by KGF (cytoprotective factor for epithelial cells) (ref. ${ }^{82}$ ) whose level increases after wounding ${ }^{94}$. The expression of Nrf2 in keratinocytes is also induced by dermal fibroblasts through the FGF, especially FGF-7 and FGF-10 (ref. ${ }^{95}$ ). The stabilization of Nrf2 (decrease the rate of degradation) is promoted by heme, which can be released from heme-proteins under stress conditions such as tissue damage or cell injury ${ }^{96}$, and due to its reactive iron molecule and lipophilic character could have harmful pro-oxidant effects ${ }^{97}$.

\section{Nrf2 inhibitors}

Under physiological conditions, the Nrf2 pathway is regulated by the Keap 1 protein that sequesters it in the cytoplasm as was mentioned above and also by postinduction repression. In this case, Keap 1 enters the nucleus, removes Nrf2 from ARE and exports it back to the cytoplasm. There the ubiquitin machinery Cullin-3 marks Nrf2 for proteasomal degradation ${ }^{98,99}$, which is related to the diminution of oxidative stress - re-entry to a normal reducing environment with the restoration of normal Nrf2 degradation ${ }^{96}$. Further, E-cadherin inhibits this pathway because it blocks Nrf2 translocation into the nucleus and also TGF- $\beta$ and some nuclear hormone receptors negatively interfere with $i^{100}$. When scientists want to evaluate whether the compound acts through the Nrf2 
pathway, they can supress it via several kinase inhibitors (without phosphorylation, Nrf2 is retained in the cytosol with Keap1) (ref. ${ }^{93}$ ), Maf-lacking ${ }^{81}$, selective bZip domain complex inhibitors (impede interaction between Nrf2 ARE interaction) (ref. ${ }^{90}$ ) and RNA interference (Nrf2 translation blocking) (ref. $\left.{ }^{93}\right)$. However, there are not many Nrf2 inhibitors yet and because some cancer cells exploit the upregulation of the Nrf2-ARE pathway for easier survival, screening for substances with a suppressive effect is now in the interest of scientists ${ }^{90}$. Of natural compounds, brusatol $^{90}$, ochratoxin ${ }^{101}$ and trigonellin ${ }^{102}$ have been were identified. During prolonged inflammation which is a consequence of impaired wound healing, associations with many pathological conditions such as fibrosis and abnormal angiogenesis up to neoplasia are observed ${ }^{103}$. And because in stressful environments, the most resistant cells are selected, the overexpression of $\mathrm{Nrf} 2$ can also be dangerous, even though it is generally considered to be a protective transcription factor.

\section{NF-кB in wound healing}

NF- $\kappa \mathrm{B}$ (nuclear factor- $\mathrm{B}$ ) monitors the expression of genes involved in inflammatory and oxidative stress response, differentiation, proliferation, apoptosis and cell adhesion ${ }^{104}$. In the cytoplasm, NF- $\mathrm{BB}$ proteins are kept in association with inhibitory $\mathrm{I} \kappa \mathrm{B}$ proteins that are degraded in response to stress stimuli. This leads to the release and activation of NF- $\mathrm{KB}$, which can translocate to the nucleus $^{104-105}$.
During wound healing, the classical NF- $\kappa \mathrm{B}$ pathway is activated (see Fig. 3) as an innate immune reaction and many cytokines, chemokines, adhesion molecules, enzymes which produce secondary inflammatory mediators, major histocompatibility complex class II antigens and inhibitors of apoptosis are created ${ }^{105}$. All these factors (IL-1 $\beta$, IL-6, IL-8, vascular cell adhesion molecule 1, intercellular adhesion molecule 1, inducible NO-synthase and cyclooxygenase-2) are essential in the early protective response against pathogens ${ }^{106}$. This is why NF-кB activation occurs in almost all cells ${ }^{107}$ during infection or injury ${ }^{108}$, especially in macrophages and epithelial cells ${ }^{109}$. This factor then becomes necessary for the migration of phagocytic and inflammatory cells to the tissues ${ }^{109}$. On the other hand, errors in NF- $\mathrm{KB}$ regulation, especially up-regulation, can cause chronic diseases (rheumatoid arthritis ${ }^{110}$, psoriasis ${ }^{111}$, diabetes mellitus, vascular complications $^{112}$, inflammatory bowel disease ${ }^{113}$, vascular inflammation and cardiovascular hypertrophy ${ }^{114}$ ). Because $\mathrm{NF}-\kappa \mathrm{B}$ also controls genes involved in cell proliferation (granulocyte colony-stimulating factor and macrophage colony-stimulating factor ${ }^{107}$ ), transformation and survival $\left(\mathrm{Bcl}-\mathrm{X}_{\mathrm{L}}, \mathrm{Bcl}-2\right)$ (ref. ${ }^{115}$ ) its anti-apoptotic and proliferative effects can facilitate tumour formation and the creation of metastases ${ }^{116}$. A key aspect is the stimulatory environment, which partly determines whether the effect of $\mathrm{NF}-\mathrm{kB}$ is protective or deleterious for the host ${ }^{106}$. During wound healing, its proliferative effect is involved in re-epithelization because it regulates keratinocyte proliferation

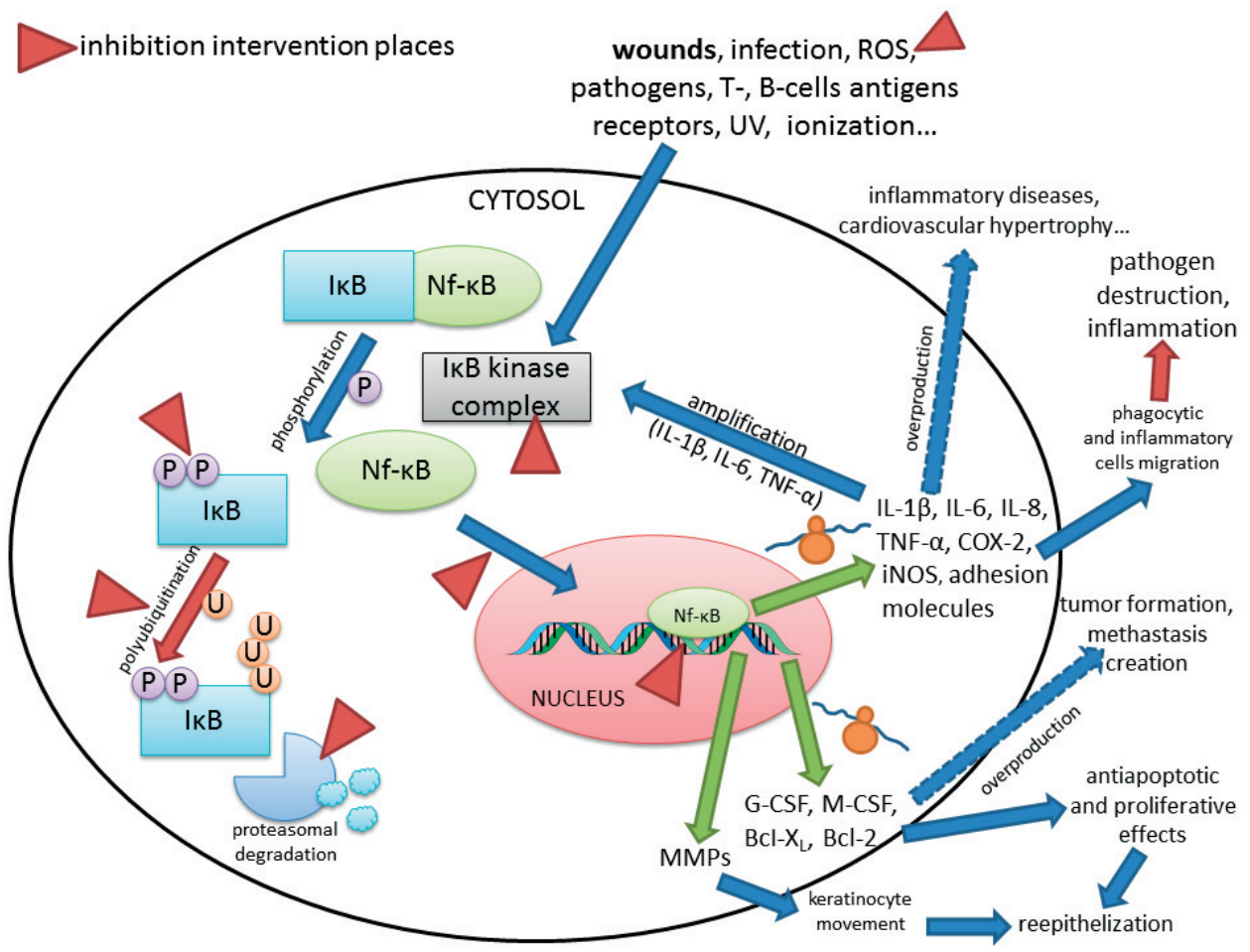

Fig. 3. Classical NF-kB pathway in wound healing.

$\mathrm{Bcl}$ - protein family regulates apoptosis; COX-2 - cyclooxygenase-2; G-CSF - granulocyte-colony

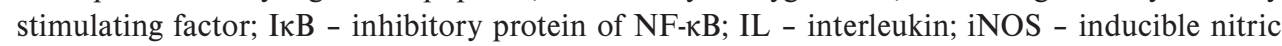
oxide synthase; M-CSF - macrophage-colony stimulating factor; NF- $\mathrm{BB}$ - nuclear factor- $\mathrm{kB}$; P phosphorylation; ROS - reactive oxygen species; TNF- $\alpha$ - tumour necrosis factor- $\alpha$; U - ubiquitination; UV - ultraviolet. 
and migration ${ }^{12,117}$. This transcription factor also controls the expression of matrix metalloproteinases ${ }^{117}$, which facilitate keratinocyte movement, modulate the secretion and stability of cytokines and growth factors for epidermal wound healing ${ }^{65}$.

\section{NF-кB inducers}

The classical NF- $\mathrm{B}$ p pathway is activated by pro-inflammatory cytokines (IL- $1 \beta$, tumour necrosis factor- $\alpha$ (ref. ${ }^{107}$ ), IL-6 (ref. $\left.{ }^{118}\right)$ ), T- and B-cells antigen receptors ${ }^{107,109}$ and angiotensin II (ref. ${ }^{119}$ ). Other inducers include viruses, bacterial lipopolysaccharides (activation via toll-like receptors which are linked to the NF- $\mathrm{kB}$ system by different adapter proteins (ref. $\left.{ }^{120}\right)$ ), some protozoan parasites (e.g. Trypanosoma cruzi), ROS (ref. ${ }^{112}$ ), phorbol ester ${ }^{121}$, laser ${ }^{122}$, UV (ref. ${ }^{107}$ ) and ionizing radiation ${ }^{123}$. There is also an amplification loop - NF- $\mathrm{kB}$ that initiates the expression of IL-6 (ref. ${ }^{118}$ ), IL-1 $\beta$ and tumour necrosis factor- $\alpha$ in the nucleus, and this leads to the other type of activation of $\mathrm{NF}-\kappa \mathrm{B}$ in the cytoplasm ${ }^{109}$. The indirect NF-кB pathway results in the release of IL- $1 \beta$ and activation of the classical NF-kB pathway in neighbouring cells ${ }^{124}$.

\section{NF- $\kappa \mathrm{B}$ inhibitors}

Overexpression of NF- $\mathrm{NB}$, as well as inadequate action can lead to impaired wound healing. In particular, prolonged inflammation, anti-apoptotic and proliferative effects are all dangerous ${ }^{106,116}$. That is why this pathway must be kept within normal limits. NF- $\mathrm{B}$ can be down-regulated by inhibition of the protein kinases that are necessary for the phosphorylation and polyubiquitination that lead to degradation of its inhibitory subunit ${ }^{125}$. Another way in which NF- $\mathrm{kB}$ activation can be repressed is using phosphatases (phosphatase 2A) (ref. ${ }^{126}$ ), proteasome inhibitors (dipeptide boronate - bortezomib) (ref. ${ }^{127}$ ), IкB ubiquitination blockers (N-tosyl-L-phenylalanine chloromethyl ketone) (ref. ${ }^{128}$ ), small peptides that cross the cell membrane and block the translocation of NF-kB into the nucleus (SN50) (ref. ${ }^{129}$ ), inhibitors of p65 acetylation (histon deacetylases) (ref. ${ }^{130}$ ) or sesquiterpene lactones that bind to DNA and occupy $\kappa B$-specific sites ${ }^{131}$. Then antioxidants with other mechanisms of effect (e.g. inhibition of ROS production), special bacterial, fungal ${ }^{104}$ and viral proteins ${ }^{132}$ can be used as NF- $\kappa$ B supressors. Of the commonly used drugs, anti-inflammatory agents (both steroid and non-steroid) (ref. ${ }^{133,134}$ ), selective estrogen receptor modulators such as raloxifene ${ }^{135}$ and immunosuppressive agents ${ }^{136}$ have an inhibitory effect on the NF-kB pathway. A detailed summary of NF- $\kappa$ B pathway inhibitors has been written by Gupta et al. (ref. ${ }^{104}$ ).

\section{Relationship between $\mathrm{Nrf} 2$ and $\mathrm{NF}-\kappa \mathrm{B}$}

To put it very simply, the Nrf2 and NF- $\kappa$ B pathways work against each other. Nrf2 protects cells against oxidative stress and inflammation, while NF- $\mathrm{BB}$ triggers an innate immune reaction and thus inflammation as well

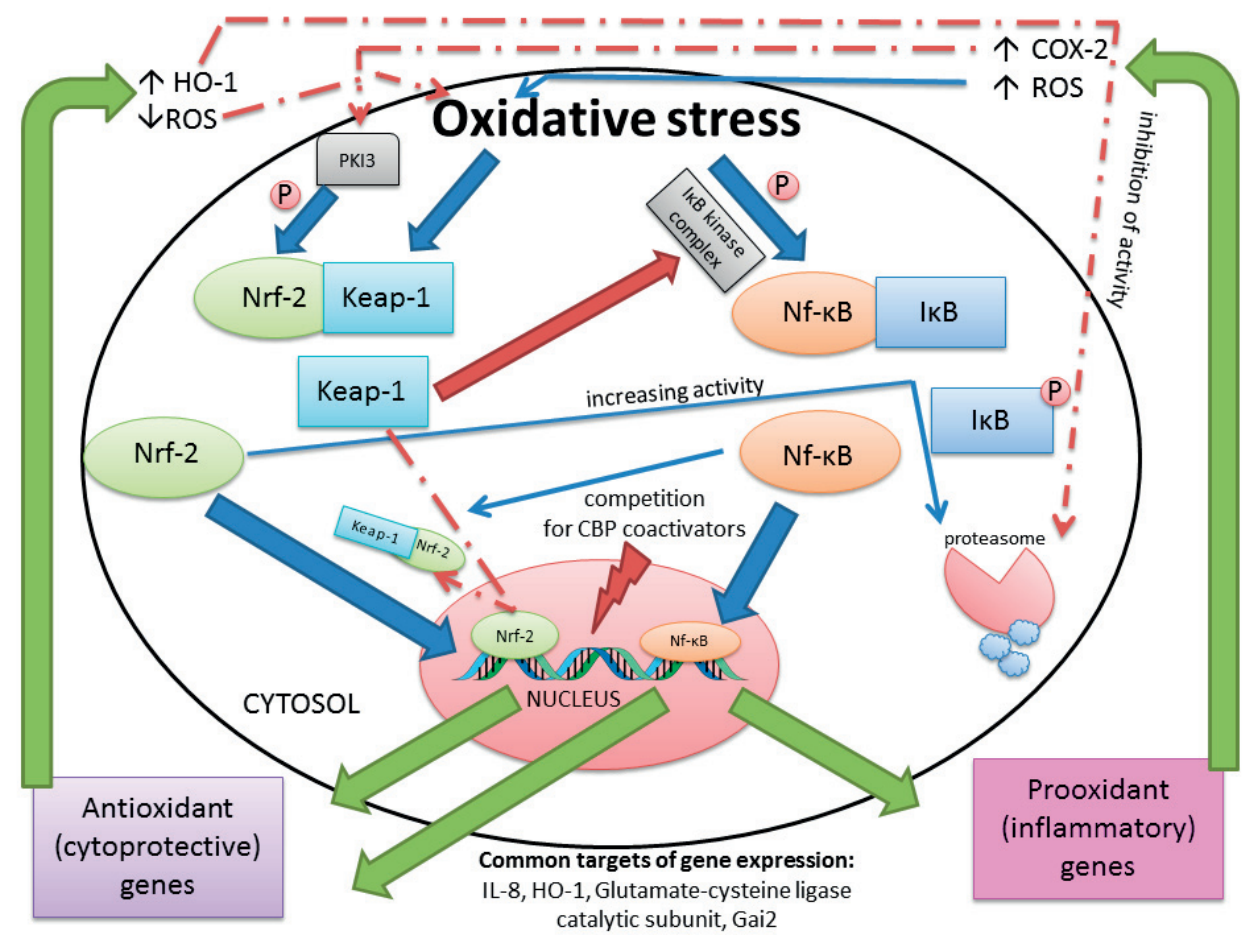

Fig. 4. The relationship between Nrf2 and NF-kB.

CBP - CREB binding protein; COX-2 - cyclooxygenase-2; Gai2 - inhibitory G protein; HO-1 -

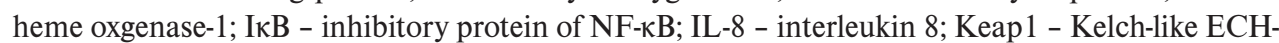
associated protein; NF-kB - nuclear factor-kB; Nrf2 - nuclear factor-erythroid 2 (NF-E2)-related factor 2; P - phosphorylation; PI3K - phosphatidylinositol 3-kinase; ROS - reactive oxygen species. 
as oxidative stress ${ }^{100,137}$. Nevertheless, there are many interconnections between their pathways. Some common genes such as IL-8, heme oxygenase-1 (HO-1), glutamatecysteine ligase catalytic subunit and inhibitory $G$ protein (Gai2) are targets for both transcription factors ${ }^{138}$. The relationship between Nrf2 and NF-kB is shown in Fig. 4.

Both pathways are activated by oxidative stress ( Nrf2 by low and NF-kB by intermediate amount of ROS) (ref. ${ }^{98}$ ) and other stimuli that lead to the release of nuclear factors from their repressors. The protein kinase complex that enables the phosphorylation and degradation of I $\mathrm{KB}$ protein (NF- $\kappa \mathrm{B}$ repressor) and therefore NF- $\kappa \mathrm{B}$ activation can be inhibited by the Nrf2 repressor Keap1 (ref. ${ }^{98}$ ). On the other hand, the NF-kB subunit p65/RelA co-imports Keap1 into the nucleus, where it terminates the effect of Nrf2 on gene transcription by exporting this factor back to the cytoplasm ${ }^{100}$. When both transcription factors reach the nucleus they need CREB binding protein (CBP) coactivators that are necessary for gene transcription. This is why the simultaneous activation of Nrf2 and NF-kB results in competition for these co-activators ${ }^{98,137}$. Some of their gene expression targets can also work against each other. NF- $\mathrm{kB}$ activates cyclooxygenase-2 (COX-2), which suppresses phosphatidylinositol 3-kinase and so inhibits the phosphorylation of Nrf2 and its release from Keap1 (ref. ${ }^{100,139}$ ). Going the other way, HO-1 activated by Nrf2 can block NF-kB translocation into the nucleus by inhibiting I $\mathrm{KB}$ protein degradation ${ }^{98,138}$. However, this information is somewhat inconsistent, because it was found that NF- $\mathrm{kB}$ also has a protective effect against ROS and this can be realized by increasing the expression of antioxidant genes such as HO-1 (ref. ${ }^{137}$ ). The return of ROS to homeostasis due to the antioxidant genes activated by Nrf2 not only causes a feedback inhibition that leads to a reduction in the activation of this transcription factor itself ${ }^{140}$, but also indirectly inhibits the NF-kB pathway. Consequently Nrf2 prevents the cellular damage of inflammation-exposed cells ${ }^{100}$

Nevertheless, these two pathways may also be activated reciprocally: oxidative stress triggered by NF- $\mathrm{BB}$ backward-activates NF- $\mathrm{BB}$ and also facilitates the translocation of $\mathrm{Nrf} 2$ into the nucleus to protect cells against inflammation and oxidative damage ${ }^{98,100,138}$. Further, Nrf2 can help the release of NF- $\mathrm{NB}$ from I $\mathrm{B}$ by increasing proteasome activity and thus potentiates the protein degradation of this inhibitory protein ${ }^{100}$.

\section{Nrf2 and NF-кB as possible markers for wound healing}

Nrf2 and NF- $\mathrm{B}$ are important during wound healing. However, it is difficult to specify how these two transcription factors can be used for evaluating wound healing. Under physiological conditions (non-stress, no injury) the levels of these two markers are minimal, so there are no defined "physiological levels" for them. It can be generally said that Nrf2 is a protective factor, but its overexpression can block the necessary immune response and insufficient activation caused prolonged inflammation ${ }^{82}$, cell damage and even neoplastic transformation ${ }^{79}$ due to inadequate antioxidant response. Similarly NF-kB is nec- essary for the correct response to infection or injury ${ }^{108}$. A lack of it impedes the accurate course of the innate immune reaction, whereas excess production may lead to inflammatory, other chronic diseases ${ }^{110-112,114}$ and tumour formation $^{116}$

Every wound is different and needs different defence and repair reactions. That is why it is practically impossible to use these two transcription factors for evaluation in clinical practice, although e.g. zero levels of these transcription factors at large non-healing wounds can be a certain indicator of an inadequate defence against oxidative stress (Nrf2) or innate immune reaction (NF-kB). The main utilization of Nrf2 and NF-kB as markers is applied in the testing of new healing compounds. For wounds with prolonged inflammation, compounds that decrease the NF-кB levels or activate the Nrf2 pathway can be useful. On the other hand in immuno-suppressed patients, NF-kB induction can help to start the correct immune reaction. Nevertheless, it is necessary to stress that the complicated network of relationships between many active molecules in the whole body can cause a different cell response than in in vivo tests.

\section{CONCLUSION}

This review briefly summarizes skin wound healing, different kinds of models for its study and the role of the transcription factors (Nrf2 and NF- $\kappa \mathrm{B}$ ) in this process and if they can be used as markers.

For researchers dealing with wound healing, it can be really difficult to select the best model for experiments. First of all, they have to know if they would like to study it in general or a particular phase/process. For the initial stages of a study, in vitro models are best due to their availability and cheapness. Nevertheless, these arrangements do not allow a holistic view, and thus in vivo assays also have to be used, usually on animals. The substances/ influences that appropriately affect skin restoration process can be later used in humans. For a closer approximation to a specific type of wound there are a number of methods for designing and conducting experiments, including various techniques and models that imitate acute and also chronic wounds. For special conditions immunosuppressed, diabetic or various gene knockout animals can be used. In silico approaches can help with the assessment and linking of vast amounts of research data.

For evaluating all these experiments, morphologic changes as well as molecules involved in wound healing can be studied and this requires proper selection of parameters and markers. Nrf2 and NF-kB act via the antiinflammatory and antioxidant effect or innate immune response in wound healing. The main effects of the above transcription factors are supplemented by many others, and thus create a complicated net with several feedback or amplification loops and interconnections. This is why increase/ decrease in given markers is valueless because it depends on the particular wound environment and state of health of the organism. The crucial activity of these 
two transcription factors in wound healing is however unquestionable.

\section{ABBREVIATIONS}

ARE, Antioxidant response elements; CBP, CREB binding protein; COX-2, Cyclooxygenase-2; (b)FG, (basic) fibroblast growth factor; HaCaT, Immortalized human skin keratinocytes; HO-1, Heme oxygenase-1; HUVEC, Human umbilical vein endothelial cells; IкB, Inhibitory protein of NF-кB; IL, Interleukin; Keap1, Kelch-like ECH-associated protein; NF- $\kappa \mathrm{B}$, Nuclear factor- $\kappa \mathrm{B} ; \mathrm{Nrf} 2$, Nuclear factor-erythroid 2 (NF-E2)-related factor 2; ROS, Reactive oxygen species; TGF, Transforming growth factor; UV, Ultraviolet.

\section{Search strategy and selection criteria}

Our research strategy was aimed at evaluating studies on the role of the transcription factors (Nrf2 and NF$\kappa \mathrm{B})$ in skin restoration to determine if they can be used as markers. Scientific articles from 1974 to 2016 were searched using the PubMed and Web of Science databases. All searches were up to date as of August 2016. The search terms used included "skin wound healing", "models for wound healing", "evaluation of wound healing", "Nrf2 in wound healing", "NF-kB in wound healing" and "interconnection between Nrf2 and NF-кB". Only English language papers were reviewed.

Acknowledgement: This work was supported by the grants from Palacky University (IGA_LF_2015_007 and IGA_LF_2016_012) and by the National Programme for Sustainability I (L01304).

Author contributions: NA: literature search, manuscript writing, figures, tables; AG: concept, critical revision; JU: critical revision.

Conflict of interest statement: The authors state that there are no conflicts of interest regarding the publication of this article.

\section{REFERENCES}

1. Gottrup F. A specialized wound-healing center concept: importance of a multidisciplinary department structure and surgica treatment facilities in the treatment of chronic wounds. Am J Surg 2004;187(5):S38-S43.

2. Thomas DR. Age-related changes in wound healing. Drugs Aging 2001;18(8):607-20.

3. Posnett J, Gottrup F, Lundgren H, Saal G. The resource impact of wounds on health-care providers in Europe. J Wound Care 2009;18(4):154-61.

4. Korybalska K, Kawka E, Breborowicz A, Witowski J. Atorvastatin does not impair endothelial cell wound healing in an in vitro model of vascular injury. J Physiol Pharmacol 2012;63(4):389-95.

5. Morain W, Colen L. Wound healing in diabetes mellitus. Clin Plast Surg 1990;17(3):493-501.

6. Kottra CJ. Wound healing in the immunosuppressed host. AORN J 1982;35(6):1142-8

7. Gondim RM, Vieira VC, Veras MM, Ferreira MA, Caldini ÉTEG, Muñoz DR, Baptista MS. Protoporphyrin fluorescence induced by methyl-ALA in skin healing. Photodiagnosis Photodyn Ther 2013;10(4):389-98.
8. Gong C, Wu Q, Wang Y, Zhang D, Luo F, Zhao X, Wei Y, Qian Z. A biodegradable hydrogel system containing curcumin encapsulated in micelles for cutaneous wound healing. Biomaterials 2013;34(27):6377-87.

9. Fan Z, Liu B, Wang J, Zhang S, Lin Q, Gong P, Ma L, Yang S. A novel wound dressing based on Ag/graphene polymer hydrogel: effectively kill bacteria and accelerate wound healing. Adv Funct Mater 2014;24(25):3933-43.

10. Kondo T, Ishida Y. Molecular pathology of wound healing. Forensic Sci Int 2010;203(1):93-8.

11. Serrano I, Díez-Marqués ML, Rodríguez-Puyol M, Herrero-Fresneda I, Dedhar S, Ruiz-Torres MP, Rodríguez-Puyol D. Integrin-linked kinase (ILK) modulates wound healing through regulation of hepatocyte growth factor (HGF). Exp Cell Res 2012;318(19):2470-81.

12. Schreml S, Szeimies R-M, Prantl L, Landthaler M, Babilas P. Wound healing in the 21st century. J Am Acad Dermatol 2010;63(5):866-81.

13. Enoch S, Leaper DJ. Basic science of wound healing. Surgery (UK) 2008;26(2):31-7.

14. Werner S, Grose R. Regulation of wound healing by growth factors and cytokines. Physiol Rev 2003;83(3):835-70.

15. Wild T, Rahbarnia A, Kellner M, Sobotka $L$, Eberlein T. Basics in nutrition and wound healing. Nutrition 2010;26(9):862-6.

16. Gill SE, Parks WC. Metalloproteinases and their inhibitors: regulators of wound healing. Int J Biochem Cell Biol 2008;40(6):1334-47.

17. Young $A, M c N a u g h t C-E$. The physiology of wound healing. Surgery (Oxford) 2011;29(10):475-9.

18. Nix DP, Bryant RA. Acute and Chronic Wounds: Current Management Concepts. Amsterdam: Elsevier Health Sciences; 2012.

19. Flanagan M. Wound Healing and Skin Integrity: Principles and Practice. Hoboken: John Wiley and Sons; 2013.

20. Velander P, Theopold C, Bleiziffer O, Bergmann J, Svensson H, Feng Y, Eriksson E. Cell suspensions of autologous keratinocytes or autologous fibroblasts accelerate the healing of full thickness skin wounds in a diabetic porcine wound healing model. J Surg Res 2009;157(1):14-20.

21. Pietramaggiori G, Scherer SS, Mathews JC, Alperovich M, Yang HJ, Neuwalder J, Czeczuga JM, Chan RK, Wagner CT, Orgill DP. Healing modulation induced by freeze-dried platelet-rich plasma and micronized allogenic dermis in a diabetic wound model. Wound Repair Regen 2008;16(2):218-25.

22. Kiwanuka E, Hackl F, Philip J, Caterson EJ, Junker JP, Eriksson E. Comparison of healing parameters in porcine full-thickness wounds transplanted with skin micrografts, split-thickness skin grafts, and cultured keratinocytes. J Am Coll Surg 2011;213(6):728-35.

23. Wong VW, Sorkin M, Glotzbach JP, Longaker MT, Gurtner GC. Surgical approaches to create murine models of human wound healing. Biomed Res Int 2010;2011

24. Gottrup F, Ågren MS, Karlsmark T. Models for use in wound healing research: a survey focusing on in vitro and in vivo adult soft tissue. Wound Repair Regen 2000;8(2):83-96.

25. Gouin J-P, Kiecolt-Glaser JK. The impact of psychological stress on wound healing: methods and mechanisms. Immunol Allergy Clin North Am 2011;31(1):81-93.

26. Coulomb B, Dubertret L. Skin cell culture and wound healing. Wound Repair Regen 2002;10(2):109-12.

27. Regnier M, Patwardhan A, Scheynius A, Schmidt R. Reconstructed human epidermis composed of keratinocytes, melanocytes and Langerhans cells. Med Biol Eng Comput 1998;36(6):821-4.

28. Groeber F, Holeiter M, Hampel M, Hinderer S, Schenke-Layland K. Skin tissue engineering -in vivo and in vitro applications. Adv Drug Deliv Rev 2011;63(4):352-66.

29. Ades EW, Candal FJ, Swerlick RA, George VG, Summers S, Bosse DC, Lawley TJ. HMEC-1: establishment of an immortalized human microvascular endothelial cell line. J Invest Dermatol 1992;99(6):683-90.

30. Murray PJ, Allen JE, Biswas SK, Fisher EA, Gilroy DW, Goerdt S, Gordon S, Hamilton JA, Ivashkiv LB, Lawrence T. Macrophage activation and polarization: nomenclature and experimental guidelines. Immunity 2014;41(1):14-20.

31. Wolf NB, Küchler $S$, Radowski MR, Blaschke T, Kramer KD, Weindl G, Kleuser B, Haag R, Schäfer-Korting M. Influences of opioids and nanoparticles on in vitro wound healing models. Eur J Pharm Biopharm 2009;73(1):34-42.

32. Walter M, Wright KT, Fuller $H$, MacNeil S, Johnson WEB. Mesenchymal stem cell-conditioned medium accelerates skin wound healing: an 
in vitro study of fibroblast and keratinocyte scratch assays. Exp Cell Res 2010;316(7):1271-81.

33. Liu X. The role of silver nanoparticles on skin wound healing, tissue remodeling and their potential cytotoxicity. A Thesis presented for the degree of PhD. in the University of Hong Kong; 2013.

34. Shi G, Wang B, Wu Q, Wang T, Wang C, Sun X, Zong W-t, Yan M, Zhao $\mathrm{Q}-c$, Chen Y. Evaluation of the wound-healing activity and anti-inflammatory activity of aqueous extracts from Acorus calamus L. Pak J Pharm Sci 2014;27(1):91-5.

35. Fusenig NE, Boukamp P. Multiple stages and genetic alterations in immortalization, malignant transformation, and tumor progression of human skin keratinocytes. Mol Carcinog 1998;23(3):144-58.

36. Wang Z, Wang Y, Farhangfar F, Zimmer M, Zhang Y. Enhanced keratinocyte proliferation and migration in co-culture with fibroblasts. PLoS One 2012;7(7):e40951.

37. Kolditz F, Krausze J, Heinz D, Niemann H, Müller-Goymann C. Wound healing potential of a dimeric In $\mathrm{B}$ variant analyzed by in vitro experiments on re-epithelialization of human skin models. Eur J Pharm Biopharm 2014;86(2):277-83.

38. Sato T, Kirimura Y, Mori Y. The co-culture of dermal fibroblasts with human epidermal keratinocytes induces increased prostaglandin $E$ 2 production and cyclooxygenase 2 activity in fibroblasts. J Invest Dermatol 1997;109(3):334-9.

39. Black AF, Berthod F, L'heureux N, Germain L, Auger FA. In vitro reconstruction of a human capillary-like network in a tissue-engineered skin equivalent. FASEB J 1998;12(13):1331-40.

40. Kim W-S, Park B-S, Sung J-H, Yang J-M, Park S-B, Kwak S-J, Park J-S. Wound healing effect of adipose-derived stem cells: a critical role of secretory factors on human dermal fibroblasts. Journal of dermatological science 2007;48(1):15-24.

41. Jeon YK, Jang YH, Yoo DR, Kim SN, Lee SK, Nam MJ. Mesenchymal stem cells' interaction with skin: Wound-healing effect on fibroblast cells and skin tissue. Wound Repair Regen 2010;18(6):655-61.

42. Pianigiani E, lerardi F, Mazzanti B, Saccardi R, Cuciti C, Fimiani M, editors. Human de-epidermized dermis as a stem cell carrier. Transplantation proceedings; 2010: Elsevier.

43. Carlson MW, Alt-Holland A, Egles C, Garlick JA. Three-Dimensional Tissue Models of Normal and Diseased Skin. Curr Protoc Cell Biol 2008:19.9. 1-.9. 7.

44. Tandon N, Cimetta E, Villasante A, Kupferstein N, Southall MD, Fassih A, Xie J, Sun Y, Vunjak-Novakovic G. Galvanic microparticles increase migration of human dermal fibroblasts in a wound-healing mode via reactive oxygen species pathway. Exp Cell Res 2014;320(1):79-91.

45. Smithmyer ME, Sawicki LA, Kloxin AM. Hydrogel scaffolds as in vitro models to study fibroblast activation in wound healing and disease. Biomater Sci 2014;2(5):634-50.

46. Fernandez TL, Van Lonkhuyzen DR, Dawson RA, Kimlin MG, Upton Z. In vitro investigations on the effect of dermal fibroblasts on keratinocyte responses to ultraviolet $\mathrm{B}$ radiation. Photochem Photobiol 2014;90(6):1332-9.

47. Weber C, Muller-Goymann C. Usefulness of a 3D skin construct in the detection of regenerative effects after previous SDS damage. J Drug Deliv Sci Technol 2009;19(5):337-42.

48. Gurjala AN, Geringer MR, Seth AK, Hong SJ, Smeltzer MS, Galiano RD, Leung KP, Mustoe TA. Development of a novel, highly quantitative in vivo model for the study of biofilm-impaired cutaneous wound healing. Wound Repair Regen 2011;19(3):400-10.

49. Tonnesen MG, Feng $X$, Clark RA. Angiogenesis in wound healing. Investig Dermatol Symp Proc 2000;5(1):40-6.

50. McGuire L, Heffner K, Glaser R, Needleman B, Malarkey W, Dickinson S, Lemeshow S, Cook C, Muscarella P, Melvin WS. Pain and wound healing in surgical patients. Ann Behav Med 2006;31(2):165-72.

51. Auerbach R, Kubai L, Knighton D, Folkman J. A simple procedure for the long-term cultivation of chicken embryos. Dev Biol 1974;41(2):391-4.

52. French SS, Matt KS, Moore MC. The effects of stress on wound healing in male tree lizards (Urosaurus ornatus). Gen Comp Endocrinol 2006;145(2):128-32.

53. Volk SW, Bohling MW. Comparative wound healing-Are the small animal veterinarian's clinical patients an improved translational model for human wound healing research? Wound Repair Regen 2013;21(3):372-81.

54. Liu J, Kim D, Brown L, Madsen T, Bouchard G. Comparison of Human, Porcine, and Rodent Wound Healing With New Miniature Swine
Study Data. In: Journal of the American association for laboratory animal science. 2009;48(5):581.

55. Oznurlu Y, Celik I, Sur E, Telatar T, Ozparlak H. Comparative skin histology of the White New Zealand and Angora rabbits: histometrical and immunohistochemical evaluations. J Anim Vet Adv 2009;8(9):1694-701.

56. Wester RC, Maibach HI. In vivo methods for percutaneous absorption measurements. J Toxicol Cutaneous Ocul Toxicol 2001;20(4):411-22.

57. Jain K, Sykes V, Kordula T, Lanning D. Homeobox genes Hoxd3 and Hoxd8 are differentially expressed in fetal mouse excisional wounds. J Surg Res 2008;148(1):45-8.

58. Nagappa A, Cheriyan B. Wound healing activity of the aqueous extract of Thespesia populnea fruit. Fitoterapia 2001;72(5):503-6.

59. Wang X-Q, Liu P-Y, Kempf M, Cuttle L, Chang AH-E, Wong M, Kravchuk $\mathrm{O}$, Mill J, Kimble RM. Burn healing is dependent on burn site: a quantitative analysis from a porcine burn model. Burns 2009;35(2):264-9.

60. Gerstenhaber JA, Brodsky R, Huneke RB, Lelkes PI. Electrospun soy protein scaffolds as wound dressings: Enhanced reepithelialization in a porcine model of wound healing. Wound Med 2014;5:9-15.

61. Seitz O, Schürmann C, Hermes N, Müller E, Pfeilschifter J, Frank $\mathrm{S}$, Goren I. Wound healing in mice with high-fat diet-or ob geneinduced diabetes-obesity syndromes: a comparative study. Exp Diabetes Res 2011;2010

62. Rowan AN. Ending the Use of Animals in Toxicity Testing and Risk Evaluation. Camb Q Healthc Ethics 2015;24(04):448-58.

63. Ojeh N, Stojadinovic O, Pastar I, Sawaya A, Yin N, Tomic-Canic M. The effects of caffeine on wound healing. Int Wound J 2014;

64. Balaji S, Moles CM, Bhattacharya SS, LeSaint M, Dhamija Y, Le LD, King A, Kidd M, Bouso MF, Shaaban A. Comparison of interleukin 10 homologs on dermal wound healing using a novel human skin ex vivo organ culture model. J Surg Res 2014;190(1):358-66.

65. Mirastschijski U, Impola U, Karsdal MA, Saarialho-Kere U, Ågren MS. Matrix metalloproteinase inhibitor BB-3103 unlike the serine proteinase inhibitor aprotinin abrogates epidermal healing of human skin wounds ex vivo1. J Invest Dermatol 2002;118(1):55-64.

66. Fredriksson C, Kratz G, Huss F. Accumulation of silver and delayed re-epithelialization in normal human skin: an ex-vivo study of different silver dressings. Wounds 2009;21(5):116-23.

67. Bouffard NA, Cutroneo KR, Badger GJ, White SL, Buttolph TR, Ehrlich $H P$, Stevens-Tuttle D, Langevin HM. Tissue stretch decreases soluble TGF- $\beta 1$ and type- 1 procollagen in mouse subcutaneous connective tissue: Evidence from ex vivo and in vivo models. J Cell Physiol 2008;214(2):389-95.

68. Shaterian A, Borboa A, Sawada R, Costantini T, Potenza B, Coimbra R, Baird A, Eliceiri BP. Real-time analysis of the kinetics of angiogenesis and vascular permeability in an animal model of wound healing. Burns 2009;35(6):811-7.

69. Sherratt JA, Dallon JC. Theoretical models of wound healing: past successes and future challenges. C R Biol 2002;325(5):557-64.

70. Cumming BD, McElwain D, Upton Z. A mathematical model of wound healing and subsequent scarring. Interface Focus 2010;7(42):19-34.

71. Menke NB, Ward KR, Witten TM, Bonchev DG, Diegelmann RF. Impaired wound healing. Clin Dermatol 2007;25(1):19-25.

72. Milatovic S, Nanney LB, Yu Y, White JR, Richmond A. Impaired healing of nitrogen mustard wounds in CXCR2 null mice. Wound Repair Regen 2003;11(3):213-9.

73. Stepp MA, Zieske JD, Trinkaus-Randall V, Kyne BM, Pal-Ghosh S, Tadvalkar G, Pajoohesh-Ganji A. Wounding the cornea to learn how it heals. Exp Eye Res 2014;121:178-93.

74. Werthen $M$, Henriksson $L$, Jensen $P \emptyset$, Sternberg $C$, Givskov $M$, Bjarnsholt T. An in vitro model of bacterial infections in wounds and other soft tissues. Apmis 2010;118(2):156-64.

75. Mustoe TA, O'Shaughnessy K, Kloeters O. Chronic wound pathogenesis and current treatment strategies: a unifying hypothesis. Plast Recontr Surg 2006;117(7S):35S-41S.

76. Ekuni D, Firth JD, Nayer T, Tomofuji T, Sanbe T, Irie K, Yamamoto T, Oka T, Liu Z, Vielkind J. Lipopolysaccharide-induced epithelial monoamine oxidase mediates alveolar bone loss in a rat chronic wound model. Am J Pathol 2009;175(4):1398-409.

77. Trøstrup H, Thomsen K, Christophersen LJ, Hougen HP, Bjarnsholt T, Jensen Pø, Kirkby N, Calum H, Høiby N, Moser C. Pseudomonas aeruginosa biofilm aggravates skin inflammatory response in $\mathrm{BALB} / \mathrm{C}$ mice in a novel chronic wound model. Wound Repair Regen 2013;21(2):292-9. 
78. Bonomo SR, Davidson JD, Tyrone JW, Lin X, Mustoe TA. Enhancement of wound healing by hyperbaric oxygen and transforming growth factor $\beta 3$ in a new chronic wound model in aged rabbits. Arch Surg 2000;135(10):1148-53.

79. auf dem Keller U, Kümin A, Braun S, Werner S. Reactive oxygen species and their detoxification in healing skin wounds. J Investig Dermatol Symp Proc 2006;11(1):106-11.

80. Ma Q. Role of nrf2 in oxidative stress and toxicity. Annu Rev Pharmacol Toxicol 2013;53:401.

81. Beyer T, Auf dem Keller U, Braun S, Schafer M, Werner S. Roles and mechanisms of action of the Nrf2 transcription factor in skin morphogenesis, wound repair and skin cancer. Cell Death Differ 2007;14(7):1250-4.

82. Braun S, Hanselmann C, Gassmann MG, auf dem Keller U, BornBerclaz C, Chan K, Kan YW, Werner S. Nrf2 transcription factor, a novel target of keratinocyte growth factor action which regulates gene expression and inflammation in the healing skin wound. Mo Cell Biol 2002;22(15):5492-505.

83. Piao MS, Choi J-Y, Lee D-H, Yun SJ, Lee J-B, Lee S-C. Differentiationdependent expression of NADP $(\mathrm{H})$ : quinone oxidoreductase-1 via NF-E2 related factor-2 activation in human epidermal keratinocytes. J Dermatol Sci 2011;62(3):147-53.

84. Lee J, Johnson J. An important role of Nrf2-ARE pathway in the cellular defense mechanism. J Biochem Mol Biol 2004;37(2):139.

85. Pedersen TX, Leethanakul C, Patel V, Mitola D, Lund LR, Danø K, Johnsen M, Gutkind JS, Bugge TH. Laser capture microdissectionbased in vivo genomic profiling of wound keratinocytes identifies similarities and differences to squamous cell carcinoma. Oncogene 2003;22(25):3964-76.

86. Kim J, Cha Y-N, Surh Y-J. A protective role of nuclear factor-erythroid 2-related factor-2 (Nrf2) in inflammatory disorders. Mutat Res 2010;690(1):12-23.

87. Schäfer M, Werner S. Transcriptional control of wound repair. Annu Rev Cell Dev Biol 2007;23:69-92.

88. Long M, de la Vega MR, Wen Q, Bharara M, Jiang T, Zhang R, Zhou S, Wong PK, Wondrak GT, Zheng $\mathrm{H}$. An essential role of NRF2 in diabetic wound healing. Diabetes 2016;65(3):780-93.

89. Sporn MB, Liby KT. Cancer chemoprevention: scientific promise, clinical uncertainty. Nat Clin Pract Oncol 2005;2(10):518-25.

90. Ma Q, He X. Molecular basis of electrophilic and oxidative defense: promises and perils of Nrf2. Pharmacol Rev 2012;64(4):1055-81.

91. Balogun E, Hoque M, Pengfei G, Killeen E, Green CJ, Foresti R, Jawed A, Motterlini R. Curcumin activates the haem oxygenase-1 gene via regulation of $\mathrm{Nrf2}$ and the antioxidant-responsive element. Biochem J 2003;371(3):887-95

92. Shin J-W, Ohnishi K, Murakami A, Lee J-S, Kundu JK, Na H-K, Ohigashi $\mathrm{H}$, Surh $\mathrm{Y}$-J. Zerumbone induces heme oxygenase-1 expression in mouse skin and cultured murine epidermal cells through activation of Nrf2. Cancer Prev Res 2011;4(6):860-70.

93. Chen H-H, Chen Y-T, Huang Y-W, Tsai H-J, Kuo C-C. 4-Ketopinoresinol, a novel naturally occurring ARE activator, induces the $\mathrm{Nrf} 2 / \mathrm{HO}-1$ axis and protects against oxidative stress-induced cell injury via activation of PI3K/AKT signaling. Free Radic Biol Med 2012;52(6):1054-66.

94. Werner S. Keratinocyte growth factor: a unique player in epithelia repair processes. Cytokine Growth Factor Rev 1998;9(2):153-65.

95. Braun S, auf dem Keller U, Steiling H, Werner S. Fibroblast growth factors in epithelial repair and cytoprotection. Philos Trans R Soc Lond B Biol Sci 2004;359(1445):753-7.

96. Alam J, Killeen E, Gong P, Naquin R, Hu B, Stewart D, Ingelfinger $J R$, Nath KA. Heme activates the heme oxygenase-1 gene in renal epithelial cells by stabilizing Nrf2. Am J Physiol Renal Physiol 2003;284(4):F743-F52.

97. Nath KA, Haggard JJ, Croatt AJ, Grande JP, Poss KD, Alam J. The indis pensability of heme oxygenase- 1 in protecting against acute heme protein-induced toxicity in vivo. Am J Pathol 2000;156(5):1527-35.

98. Bellezza I, Mierla AL, Minelli A. Nrf2 and NF-KB and their concerted modulation in cancer pathogenesis and progression. Cancers 2010;2(2):483-97.

99. Sun Z, Wu T, Zhao F, Lau A, Birch CM, Zhang DD. KPNA6 (Importin a7)mediated nuclear import of Keap1 represses the Nrf2-dependent antioxidant response. Mol Cell Biol 2011;31(9):1800-11.

100. Geismann C, Arlt A, Sebens S, Schafer H. Cytoprotection "gone astray": Nrf2 and its role in cancer. Onco Targets Ther 2014;7:1497518.
101. Limonciel A, Jennings P. A review of the evidence that ochratoxin A is an Nrf2 inhibitor: implications for nephrotoxicity and renal carcinogenicity. Toxins 2014;6(1):371-9.

102. Arlt A, Sebens S, Krebs S, Geismann C, Grossmann M, Kruse M, Schreiber S, Schäfer H. Inhibition of the Nrf2 transcription factor by the alkaloid trigonelline renders pancreatic cancer cells more susceptible to apoptosis through decreased proteasomal gene expression and proteasome activity. Oncogene 2013;32(40):4825-35.

103. Hanahan D, Weinberg RA. Hallmarks of cancer: the next generation. Cell 2011;144(5):646-74.

104. Gupta SC, Sundaram C, Reuter S, Aggarwal BB. Inhibiting NF-кB activation by small molecules as a therapeutic strategy. Biochim Biophys Acta Gene Regul Mech 2010;1799(10):775-87.

105. Ghosh S, May MJ, Kopp EB. NF-KB and Rel proteins: evolutionarily conserved mediators of immune responses. Annu Rev Immunol 1998; 16(1):225-60.

106. Jobin C, Sartor RB. The ІкB/NF-kB system: a key determinant of mucosal inflammation and protection. Am J Physiol Cell Physiol 2000;278(3):C451-C62.

107. Oeckinghaus A, Ghosh S. The NF-KB family of transcription factors and its regulation. Cold Spring Harb Perspect Biol 2009;1(4):a000034

108. May MJ, Ghosh S. Rel/NF-KB and IKB proteins: an overview. Semin Cancer Biol 1997;8(2):63-73.

109. Bonizzi G, Karin M. The two NF-KB activation pathways and their role in innate and adaptive immunity. Trends Immunol 2004;25(6):280-8.

110. Tak PP, Gerlag DM, Aupperle KR, Van De Geest DA, Overbeek M Bennett BL, Boyle DL, Manning AM, Firestein GS. Inhibitor of nuclear factor $\mathrm{kB}$ kinase $\beta$ is a key regulator of synovial inflammation. Arthritis Rheum 2001;44(8):1897-907.

111. Lizzul PF, Aphale A, Malaviya R, Sun Y, Masud S, Dombrovskiy V, Gottlieb AB. Differential expression of phosphorylated NF-KB/ RelA in normal and psoriatic epidermis and downregulation of NF-KB in response to treatment with etanercept. J Invest Dermatol 2005;124(6):1275-83.

112. Sen CK, Packer L. Antioxidant and redox regulation of gene transcription. FASEB J 1996;10(7):709-20.

113. Schreiber $S$, Nikolaus $S$, Hampe J. Activation of nuclear factor kB in inflammatory bowel disease. GUT 1998;42(4):477-84.

114. Brasier AR. The NF-KB regulatory network. Cardiovasc Toxicol 2006;6(2):111-30.

115. Burstein E, Duckett CS. Dying for NF-KB? Control of cell death by transcriptional regulation of the apoptotic machinery. Curr Opin Cell Biol 2003;15(6):732-7.

116. Ben-Neriah Y, Karin M. Inflammation meets cancer, with NF-kappa $B$ as the matchmaker. Nat Immunol 2011;12(8):715-23.

117. Na J, Lee K, Na W, Shin J-Y, Lee M-J, Yune TY, Lee HK, Jung H-S, Kim WS, Ju B-G. Histone H3K27 demethylase JMJD3 in cooperation with NF-KB regulates keratinocyte wound healing. J Invest Dermatol 2016;

118. Ogura H, Arima Y, Kamimura D, Murakami M. The gateway theory: How regional neural activation creates a gateway for immune cells via an inflammation amplifier. Biomed J 2013;36(6):269.

119. Brasier AR, Recinos A, Eledrisi MS. Vascular inflammation and the renin-angiotensin system. Arterioscler Thromb Vasc Biol 2002;22(8):1257-66.

120. Salminen A, Huuskonen J, Ojala J, Kauppinen A, Kaarniranta K, Suuronen T. Activation of innate immunity system during aging: NF-kB signaling is the molecular culprit of inflamm-aging. Ageing Res Rev 2008;7(2):83-105.

121. Schreck R, Grassmann R, Fleckenstein B, Baeuerle P. Antioxidants selectively suppress activation of NF-kappa B by human T-cell leukemia virus type I Tax protein. J Virol 1992;66(11):6288-93.

122. Chen AC, Arany PR, Huang Y-Y, Tomkinson EM, Sharma SK, Kharkwal GB, Saleem T, Mooney D, Yull FE, Blackwell TS. Low-level laser therapy activates NF-kB via generation of reactive oxygen species in mouse embryonic fibroblasts. PLoS One 2011;6(7):e22453.

123. Brach M, Hass R, Sherman M, Gunji H, Weichselbaum R, Kufe D. lonizing radiation induces expression and binding activity of the nuclear factor kappa B. J Clin Invest 1991;88(2):691.

124. Wickremasinghe MI, Thomas LH, Friedland JS. Pulmonary epithelia cells are a source of IL-8 in the response to Mycobacterium tuberculosis: essential role of IL-1 from infected monocytes in a NF-KBdependent network. J Immunol 1999;163(7):3936-47. 
125. Karin M. How NF-KB is activated: the role of the IKB kinase (IKK) complex. Oncogene 1999;18(49)

126. Barisic S, Strozyk E, Peters N, Walczak H, Kulms D. Identification of PP2A as a crucial regulator of the NF-KB feedback loop: its inhibition by UVB turns NF-KB into a pro-apoptotic factor. Cell Death Differ 2008;15(11):1681-90.

127. Allen C, Saigal K, Nottingham L, Arun P, Chen Z, Van Waes C. Bortezomib-induced apoptosis with limited clinical response is accompanied by inhibition of canonical but not alternative nuclear factor-кB subunits in head and neck cancer. Clin Cancer Res 2008;14(13):4175-85.

128. Higuchi M, Singh S, Chan H, Aggarwal B. Protease inhibitors differentially regulate tumor necrosis factor-induced apoptosis, nuclear factor-kappa B activation, cytotoxicity, and differentiation. Blood 1995;86(6):2248-56.

129. Lin Y-Z, Yao S, Veach RA, Torgerson TR, Hawiger J. Inhibition of nuclear translocation of transcription factor NF-KB by a synthetic peptide containing a cell membrane-permeable motif and nuclear localization sequence. J Biol Chem 1995;270(24):14255-8.

130. Chen Lf, Mu Y, Greene WC. Acetylation of RelA at discrete sites regulates distinct nuclear functions of NF-KB. EMBO J 2002;21(23):6539-48

131. Zhang S, Won Y-K, Ong C-N, Shen H-M. Anti-cancer potential of sesquiterpene lactones: bioactivity and molecular mechanisms. Curr Med Chem Anticancer Agents 2005;5(3):239-49.

132. Hiscott J, Nguyen TA, Arguello M, Nakhaei P, Paz S. Manipulation of the nuclear factor-KB pathway and the innate immune response by viruses. Oncogene 2006;25(51):6844-67.

133. De Bosscher K, Berghe WV, Haegeman G. Cross-talk between nuclear receptors and nuclear factor KB. Oncogene 2006;25(51):6868-86

134. Takada Y, Bhardwaj A, Potdar P, Aggarwal BB. Nonsteroidal antiinflammatory agents differ in their ability to suppress NF-KB activation, inhibition of expression of cyclooxygenase-2 and cyclin D1, and abrogation of tumor cell proliferation. Oncogene 2004;23(57):9247-58.

135. Kalaitzidis D, Gilmore TD. Transcription factor cross-talk: the estrogen receptor and NF-KB. Trends Endocrinol Metab 2005;16(2):46-52.

136. Meyer S, Kohler NG, Joly A. Cyclosporine A is an uncompetitive inhibitor of proteasome activity and prevents NF-KB activation. FEBS Lett 1997;413(2):354-8.

137. Morgan MJ, Liu Z-g. Crosstalk of reactive oxygen species and NF-KB signaling. Cell Res 2011;21(1):103-15.

138. Wakabayashi N, Slocum SL, Skoko JJ, Shin S, Kensler TW. When NRF2 talks, who's listening? Antioxid Redox Signal 2010;13(11):1649-63.

139. Healy ZR, Lee NH, Gao X, Goldring MB, Talalay P, Kensler TW, Konstantopoulos K. Divergent responses of chondrocytes and endothelial cells to shear stress: cross-talk among COX-2, the phase 2 response, and apoptosis. Proc Natl Acad Sci U S A 2005;102(39):14010-5.

140. Bekyarova G, Tzaneva M. Melatonin Ameliorates Burn-Induced Liver
Injury by Modulation of Nrf2 and Nf-kB Signaling Pathways. SOJ immunol 2015;3(2). doi:10.15226/soji/3/2/00128

141. Anderson RR, Farinelli W, Laubach H, Manstein D, Yaroslavsky AN, Gubeli J, Jordan K, Neil GR, Shinn M, Chandler W. Selective photothermolysis of lipid-rich tissues: a free electron laser study. Lasers Surg Med 2006;38(10):913-9.

142. Andrews SN, Jeong E, Prausnitz MR. Transdermal delivery of molecules is limited by full epidermis, not just stratum corneum. Pharm Res 2013;30(4):1099-109.

143. Calabro K, Curtis A, Galarneau J-R, Krucker T, Bigio IJ. Gender variations in the optical properties of skin in murine animal models. J Biomed Opt 2011;16(1):011008.

144. Çömelekoğlu Ü, Yalin S, Balli E, Berköz M. Ovariectomy decreases biomechanical quality of skin via oxidative stress in rat. Turk J Med Sci 2012;42(2):201-9.

145. Lynch SE, Colvin RB, Antoniades HN. Growth factors in wound healing. Single and synergistic effects on partial thickness porcine skin wounds. J Clin Invest 1989;84(2):640-6.

146. Ma T, Hara M, Sougrat R, Verbavatz J-M, Verkman A. Impaired stratum corneum hydration in mice lacking epidermal water channel aquaporin-3. J Biol Chem 2002;277(19):17147-53.

147. Monteiro-Riviere NA, Bristol DG, Manning TO, Rogers RA, Riviere JE. Interspecies and interregional analysis of the comparative histologic thickness and laser Doppler blood flow measurements at five cutaneous sites in nine species. J Invest Dermatol 1990;95(5):582-6.

148. Ngawhirunpat T, Hatanaka T, Katayama K, Yoshikawa H, Kawakami J, Adachi I. Changes in electrophysiological properties of rat skin with age. Biol Pharm Bull 2002;25(9):1192-6.

149. Noisakran S, Onlamoon N, Songprakhon P, Hsiao H-M, Chokephaibulkit K, Perng GC. Cells in dengue virus infection in vivo. Adv Virol 2010;2010.

150. Pires-de-Campos MSM, Leonardi GR, Chorilli M, Spadari-Bratfisch RC, Polacow MLO, Grassi-Kassisse DM. The effect of topical caffeine on the morphology of swine hypodermis as measured by ultrasound. J Cosmet Dermatol 2008;7(3):232-7.

151. Sabourin CL, Danne MM, Buxton KL, Casillas RP, Schlager JJ. Cytokine, chemokine, and matrix metalloproteinase response after sulfur mustard injury to weanling pig skin. J Biochem Mol Toxicol 2002;16(6):263-72.

152. Sokolov VE. Mammal skin. Oakland: University of California Press; 1982.

153. Vargas G, Chan EK, Barton JK, Rylander HG, Welch AJ. Use of an agent to reduce scattering in skin. Lasers Surg Med 1999;24(2):13341.

154. Yagci A, Zik B, Uguz C, Altunbas K. Histology and morphometry of white New Zealand rabbit skin. Indian Vet J 2006;83(8):876-80.

155. Behm B, Babilas P, Landthaler M, SchremI S. Cytokines, chemokines and growth factors in wound healing. J Eur Acad Dermatol Venereol 2012;26(7):812-20. 